\title{
Preservation of Public Security Through Executive Restraint of Personal Liberty: A Case Study of the Kenyan Position
}

\author{
By Albert O. Mumma
}

\section{Introduction}

At one time or another, the problem of reconciling the need to maintain public security with the need to protect human rights arises in all societies - in particular with the right to liberty of the person - which is equally important. In Kenya, like in several other countries faced with the same dilemma, a compromise formula has been arrived at in the form of an entrenched Bill of Rights - with pride of place given to the right to liberty - which has provisions for "derogations from [ these] fundamental rights and freedoms. " ${ }^{1}$ In relation to the right to liberty, the derogatory provisions connote what, in common parlance, is referred to as »detention without trial«. This »detention without trial» is the subject of this paper.

Focus will be on three aspects of the problem:

(1) The constitutional basis of the laws governing detention without trial.

(2) The safeguards - constitutional or otherwise - that have been erected to protect the individual from an arbitrary application of the laws.

(3) The extent to which these saf eguards have realized their set objectives.

Two hypotheses will be pursued. First, that the laws governing detention without trial currently in force lack constitutional validity. Second, that the saf eguards provided against the arbitrary application of these laws have been significantly ineffective. And, the perspective will be that of constitutionalism.

The concept of constitutionalism has as its aim to limit the arbitrariness of political power. ${ }^{2}$ It requires that government is conducted according to predetermined rules and not according to the momentary whims and caprices of the rulers. ${ }^{3}$ Therefore, the question which arises concerns the nature or content of the restraints imposed on the government.

According to Nwabueze, mindividual civil liberties are indeed the very essence of coristitutinal government $«{ }^{4}$ The Kenyan political system is premised upon this theory. ${ }^{5}$ Hence, the adoption of the perspective of constitutionalism.

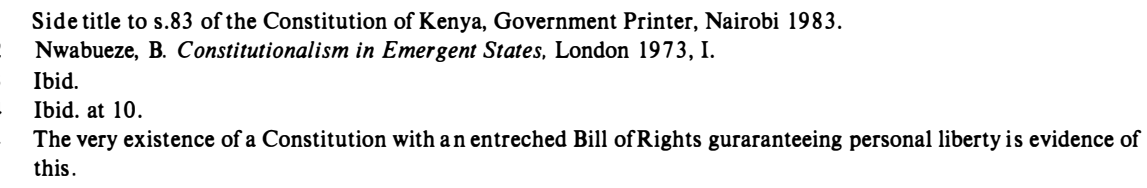




\section{Historical Outline of Detention Laws in Kenya}

The "Petition of Rights " (1627) which resulted from the great constitutional struggle of the 17 th century in Britain, among other things, deprived the Crown of the power to imprison, without laying a criminal charge, those who were considered to be dangerous to the security of the State. From this time on, only Parliament had the capacity to confer the powers of arrest and detention. Towards this end, Parliament adopted the use of statutes which confer broad emergency powers on the executive to enact subordinate legislation under which it could provide for the detention of persons. ${ }^{6}$

It was in this guise that detention laws first appeared in Kenya. The 1897 East African Order in Council ${ }^{7}$ made under the Foreign Jurisdictions Act of 1890 empowered the Commissioner of the East African Protectorate to make the laws for the administration of the Protectorate. The Commissioner duly made regulations called the Native Courts Regulations. ${ }^{8} \mathrm{~S} .77$ provided for the detention of persons.

TheNative Courts Regulations were repealed by the Courts Ordinance in $1907 .{ }^{9}$ Before this repeal, the detention provision contained in $\mathbf{5 . 7 7}$ of the Native Courts Regulations had, in 1904, been transferred to s. 2 of the Removal of Natives Within Special Districts Ordinance. ${ }^{10}$ Therefore, s. 77 of the Native Courts Regulations was absent from the 1907 Courts Ordinance.

The 1904 Ordinance was repealed by the Removal of Natives Ordinance of $1908 .{ }^{11} \mathrm{~S} .2$ of this Ordinance provided for detention. The 1908 Ordinance was in its turn repealed by the Removal of Natives Ordinance of $1909^{12}$ s.3 of which contained the detention provision. The 1909 Ordinance was repealed by the Deportation Ordinance of $1923^{13} \mathrm{~s} .5$ of which provided for detention. Finally, the 1923 Ordinance was repealed by the Deportation (A1iens) Ordinance of $1949 .{ }^{14} \mathrm{This}$ time the Ordinance did not provide for detention and this marked the end of the use of this series of Ordinances for the detention without trial of political offenders.

Notable about this series of Ordinances is that they provided for detention of persons, not just in times of emergency, but at all times.

Before the cessation of their use in 1949, a different type of detention laws was introduced in 1939 by the Emergency Powers Order in Council. ${ }^{15}$ This was the applicaton in Kenya of the 1939 Emergency Powers (Defence) Act of England. S.2(a) of this Act provided for the

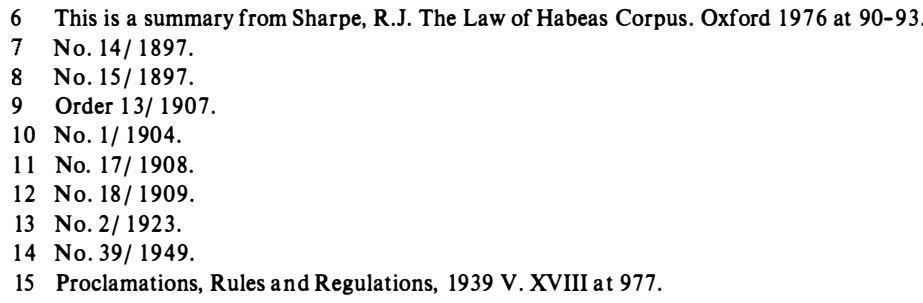


"detention of persons whose detention appears to the Secretary of State to be expedient ... Unlike these under the previous Ordinances, these powers were temporary. S. 11 (1) provided that these powers were to operate for one year only, after which they were to lapse unless extended by Parliament for another year.

With independence, a Bill of Rights was entrenched in the 1963 Independence Constitution to facilitate the protection of individual rights. S.10 repealed the 1939 Emergency Powers Order in Council while s.16 guaranteed the right to personal liberty. ${ }^{16}$ But Kenya had not seen the last of detentions without trial, because s.29 of the same Constitution provided for the declaration of emergency during which derogation from $\mathrm{s} .16$ was permitted if passed under the authority of an Act of Parliament.

That Act was the Preservation of Public Security Act ${ }^{17}$ s. 4 of which authorised the Governor to "make provisions for the detention of persons"S.29(6) required Parliament to review the declaration of emergency every two months.

In 1966, sections 83 and 85 of the Constitution (previously sections 16 and 29 respectively of the Independence Constitution) were amended. ${ }^{18}$ The Preservation of Security Act was also amended. The term "emergency « was replaced by the term "public security «. ${ }^{19}$ The period for parliamentary review of the emergency order was increased from two months to eight months. Also, greater and wider derogations from the rights guaranteed in the Bill of Rights were permitted. Significantly, the number of guaranteed rights increased from two the right to personal liberty and protection from discrimination - to six, protection against arbitrary search or entry, freedom of expression, assembly and association, and freedom of movement being added to the list. ${ }^{20}$ Also, the requirement that derogation must be reasonably justifiable in the circumstances of the situation, was removed.

Subsequently, an Order ${ }^{21}$ brought Part III of the Preservation of Public Security Act into operation, and the executive invoked the powers granted to it by sections $4(2)$ (a) and (b) of this Act. Significantly, these sub-sections provide for the detention of persons, the registration of persons and restriction of movement, and the compulsory movement of persons, including the imposition of curfews.

The requisite regulations were duly passed ${ }^{22}$ and, under them, detailed rules governing the detention of persons were also made. ${ }^{23}$ Also, the President delegated his power of detention to the Minister of Home Affairs. ${ }^{24}$

16 Independence Constitution, Government Printer, Nairobi, 1963.

17 Cap. 57 of the Laws of Kenya, Government Printer, Nairobi. This Act had actually made its appearance in 1960 under the name, The Preservation of Public Security Ordinance. Thus, in 1963, its operation was simply linked to s.29 of the Constitution, meaning that, henceforth, it would only operate during an emergency declared under s. 29 of the Constitution.

18 Act. No. 18/1966.

19 Kenya House of Representatives Official Reports, v.9 Part 1 (1966), Government Printer, Nairobi 278-279.

20 Sections $76,79,80$ and 81 of the Constitution in that order. Formerly only sections 72 and 82 could be derogated from.

21 The Constitution (Public Security) Order, L.N. 211/ 1966.

22 L.N. 212/ 1966.

23 L.N. $241 / 1966$.

24 R. 6(1) of the Preservation of Public Security (Detained and Restricted Persons) Regulations at s.29. 
The final amendment to the laws governing detention of persons without trial occurred in $1968^{25}$ when the schedule to the Act which required parliamentary review of the Order bringing Part III of the Preservation of Public Security Act into operation every eight months was deleted.

Once again, the detention laws were a permanent feature of life capable of being resorted to at any time rather than only in times of emergency.

Finally, s.85(5) of the Constitution requires that whenever a change results in the holder of the Office of the Presidency, the Order under which detentions are carried out lapses on the seventh day. Therefore, on the ascendancy of President Moi to the Presidency, the Constitution (Public security) $\operatorname{Order}^{26}$ replaced the previous one, and under it similar regulations ${ }^{27}$ and Rules ${ }^{28}$ were once again made enabling detention of persons to be carried out under the new President. Parliamentary approval was duly given on the 31 st of October, $1978 .^{29}$

It is time now to consider the constitutional basis of these laws.

\section{The Constitutional Basis of the Detention Laws in Kenya}

S.72 of the Constitution states that no person shall be deprived of his personal liberty save as may be authorised by law. The section then authorises three kinds of restraint on personal liberty, that is, control of movement, restriction of movement and detention. ${ }^{30}$ Control of movement includes the use of passports, systems of identity cards or papers, and the registration of aliens. Restriction of movement may take the form of limitation of residence to a particular place or the prohibition of visits or residence in certain areas or the prohibition of journeys for certain purposes.

Types of authorised detention are: First, detention as a measure of social control or protection. This is allowed in the case of a person under eighteen years of age for the purpose of his education or welfare and, in the case of a person reasonably suspected of being of unsound mind, addicted to drugs or alcohol, or a vagrant, for the purpose of care or treatment or for the protection of the community. Second, detentions are authorised to prevent the spread of disease or to facilitate the admission or expulsion of persons from the country. Finally, there is detention under criminal law and procedure. Some cases concern the deprivation of liberty in connection with the execution of court orders. Others concern the arrest of a person reasonably suspected of having committed or, being about to commit a crime. In these instances, the person detained must be brought to court as soon as reasonably prac-

25 Act No. 45/ 1968.

26 L.N. $222 / 1978$.

27 L.N. $234 / 1978$.

28 L.N. $235 / 1978$.

29 Båraza La Taifa, Taarifa Rasmi, V.XIVIII, September 12, 1978 - November 3, 1978, Government Printer, Nairobi.

30 Detentions here distinguished from detention without trial. 
ticable and, unless that is done within twenty-four hours, the onus of proving that the provisions of $\mathrm{s} .72$ have been complied with will be on the detaining authority. Once a person has been brought before a court, his further detention can be valid only after an order of the court. A person detained on reasonable suspicion of having committed or being about to commit a crime, unless tried within a reasonable time, has to be released without prejudice to further proceedings, either unconditionally or upon reasonable conditions, in particular to ensure his appearance at the trial or preliminary proceedings.

Any deprivations of liberty that do not fall within the confines of 5.72 can thus only be constitutional if done under the authority of s.83.

S.83 will be analysed within the general framework of emergency legislation because the Preservation of Public Security Act, made thereunder, is emergency legislation. This can be gathered from the words of the Attorney General of the time who, when tabling the Bill said:

"(...) situations can arise or may be provoked where the government has to take special measures (. . . ). In some systems of law this situation is called an emergency (...)

The word "emergency" is unnecessary and may be misleading. Furthermore, it has for us the most distasteful associations of memory. We prefer to talk about our public security. ${ }^{31}$

The distinction is therefore semantical and not substantive.

\section{Emergencies}

According to Nwabueze:

"In its ordinary meaning, an emergency seems to presuppose some event, usually of a violent nature, endangering or threatening public order or public safety (...). The danger or threat must be an imminent one, and the event giving rise to it must involve a considerable section of the public, since only so can public danger or public safety be said to be in jeopardy. " $^{32}$

This is Kenya's understanding also of an emergency for, when proposing the constitutional amendment, the Attorney General at the time said:

"Internal disorder may take many forms. It may be the case of a major attempt to overthrow the legitimate government. It may be the case of a few fanatics (religious or political) causing unrest leading to riots and local dis order (..)... ${ }^{33}$

It is widely recognised that constitutionalism has to be limited by the exigencies of an emergency. ${ }^{34}$ The justification provided for this is that the preservation of the State and of society is an imperative necessity which should override the need for limited government. ${ }^{35}$ Accordingly all constitutions which impose limitations upon government authorise the limitations to be exceeded in times of emergency. ${ }^{36}$

31 House of Representatives Official Reports supra at n.19 at 278-9. (Emphasis added).

32 Supra at $n .2$ at 175.

33 Supra at $n .19$ at 273.

34 Nwabueze Supra at n.2 at 174.

35 Ibid.

36 Ibid. 
In the Lawless Case ${ }^{37}$ the European Commission of Human Rights set out four criteria to be used in deciding whether or not a public emergency exists. ${ }^{38}$

1. It must be actual or imminent;

2. It must involve the whole nation;

3. The continuance of the organised life of the community must be threatened;

4. The crisis or danger must be exceptional in that normal measures for the maintenance of public safety, health and order are plainly inadequate.

The Commission concluded that a combination of the following facts made it reasonable for the Irish government to take the view that a public emergency existed on 5th July, 1957:

1. The existence of a secret army engaged in unconstitutional activities within the territory of the Republic of Ireland and using violence to attain its purposes;

2. The fact that this army was operating outside the territory of the State, thus seriously jeopardising the relations of the Republic of Ireland with its neighbour;

3. The steady and alarming increase in terrorist activities from the autumn of 1956 and throughout the first half of 1957.

The situation in Kenya on the 17th October, 1978, the date of the Constitution (Public Security) Order ${ }^{39}$ which brought Part III of the Preservation of Public Security Act into operation (i.e. declared an emergency), and thus enabled detentions of persons without trial to be carried out, will now be analysed in order to determine whether a state of emergency, satisfying the above criteria, existed to warrant such action.

\section{The Situation}

On 13th October, 1978, the Standard quoted the Financial Times as having written that:

"In a continent plagued by political turmoil, the stability that Kenyatta gave Kenya seems to have survived his death. Power has passed from one pair of hands to another in a calm and meticulously constitutional fashion. ${ }^{40}$

It also quoted the Zambian Daily as having:

"(...) praised Kenya's smooth change of leadership, proving wrong the prophets of doom who predicted a power struggle after the death of Kenyatta. Kenya today is a haven of peace. $\aleph^{41}$

And it was not just outsiders who thought that Kenya was a haven of peace. President $\mathrm{Moi}$ himself, on 6th November, 1978 is reported to have "advised all policemen to improve the

37 Lawless v. Ireland Application No. 332/ 1957, Year-Book of the European Convention $2(1958 / 59)$ at 308.

38 The information that follows was gathered from F. van Hoof, "The Protection of Human Rights and the Impact of Emergency Situations Under International Law with special reference to the present situation in Chile Human Rights Journal VX (1977), at 236. See also Bridge, Lasok and Plender (eds.), Fundamental Rights, Sweet \& Maxwell, (1973) - the article - McGovern. E.T., "Internment and Detention Without Trial in the Light of the European Convention on Human Rights", at 223.

39 L.N. 222/1978.

40 Standard Newspapers Ltd., Nairobi at 1.

41 Ibid. 
haven of peace and tranquility which prevails . . $\wedge^{42}$ These, surely, cannot be the words of a President who has an emergency to deal with. Other factors reinforce the conclusion that no emergency existed at the time.

First, s.85(5) provides that wherever a change results in the holder of the office of the presidency, the Order made under that section by the previous holder of that office, ceases to have effect on the seventh day after the change. President Moi was elected President on 10th October, 1978. The Constitution (Public Security) Order was passed on the 17th October, 1978, exactly the day the Order valid in the term of the previous President was to lapse. The conclusion that the prime motive here was to have continuity of operation rather than to deal with any prevalent emergency situation, is a valid one.

Secondly, s.4(2) of the Preservation of Public Security Act Contains provisions for thirteen different types of emergency measures. Significantly, only the two measures that provide for detention without trial of persons ${ }^{43}$ and, restriction of movement, compulsory movement of persons and imposition of curfews ${ }^{44}$ were brought into operation. Once again, it is arguable that the prime motive in bringing Part III of the Act into operation was to legitimise deprivations of personal liberty, rather than to deal with any emergency situation.

As has been argued, emergency provisions are constitutional only if invoked to deal with a prevailing emergency situation. Kenya's Constitution is premised on this theory. Therefore, since Part III of the Preservation of Public Security Act was brought into operation for reasons other than to deal with a prevailing emergency situation, the constitutional validity of the detentions without trial carried out under it is, at best, doubtful.

A second factor throws even more doubt on its constitutionality. Emergency powers can only be accommodated within the concept of constitutionalism if they are conceived of as "an ephemeral aberration occurring once in a long while. ${ }^{45}$ If this were not the case, legislation introduced in response to an exceptional threat would take the place of the ordinary laws of the land. Emergency powers, to be constitutional, must be temporary.

\section{Temporariness}

The nature and purpose of international human rights law imply that any suspension or restriction of fundamental human rights and freedoms be restricted to the shortest period of time possible. ${ }^{46}$ Therefore, most emergency legislation is based on the idea that emergency measures must be withdrawn as soon as the situation justifying such measures has ceased to exist.

Kenya subscribes to this theory. According to the Attorney General of the time:

"It is not uncommon to find in the Constitution or in the common law of a country an exceptional power of law-making vested in executive to deal with (...) conditions of emergency (...). It is of the essence of the rule of law in a free society that the law-

42 The Daily Nation, Nairobi at 4.

43 S. 4 (2) (a).

44 S. 4 (2) (b).

45 Nwabueze supra at $n .2$ at 174.

46 van Hoof supra at n. 38 . 
making power of the executive (...) should only be given by Parliament (...). The Government should be responsible to Parliament for its exercise of these powers. Now let us apply these principles to this measure (...)

Parliament may revoke these powers at any time (. . .). Parliament must review the special powers within every period of eight months. (17 $^{77}$

Subsequent events drastically undermined the strength of the Attorney General's argument. In 1968, a bare two years after the Attorney General's speech, the constitutional provision that required Parliamentary review of these special powers every eight months was deleted in a constitutional amendment. ${ }^{48}$ This deletion seriously undermined the constitutional validity of these exceptional powers for, as the Attorney General had pointed out, that validity depended on two factors, one of which was the periodic parliamentary review.

The second factor was Parliament's power to "revoke these powers at any time." Although technically correct it assumes too much to say that Parliament may so do, particularly when this power is put in its proper Kenyan context.

S.85(4) of the Constitution requires a resolution supported by a majority of all members of Parliament, to revoke the Order bringing these special powers into operation. It is the argument of this paper that this majority would be unobtainable in the Kenyan circumstances.

First, Kenya is a one party State. ${ }^{49}$ Therefore, all members of the National Assembly are also members of the ruling party, the Kenya African National Union (KANU). It is extremely unlikely that a majority of KANU members of Parliament would unite to revoke powers invoked by a KANU executive against the wishes of that executive.

Second, seventy-five of the one hundred and seventy voting members of Parliament are also members of the Cabinet. ${ }^{50}$ These members are bound by the principle of collective responsibility ${ }^{51}$ and it is unlikely that they would break ranks to vote for the revocation of these special powers as long as there is no cabinet decision to revoke them. This factor assumes added significance in view of the fact that another twelve members of Parliament are nominated by the President. The members of Parliament who are neither members of the cabinet nor nominated are outnumbered by eight. Thus, the executive has a clear majority in Parliament and would be unlikely to lose on a vote to revoke the special powers against its wishes. ${ }^{52}$

Third, members of the National Assembly have to date evidenced extreme apathy as regards matters touching on detention of persons without trial. Commenting on this apathy, Martin Shikuku, M.P., said:

"Now if we all support the present President, surely . . . every member would not like to get when he brings a motion and says, "Now how about reviewing this case? they will

47 House of Representatives Debates supra at no 19 at 277 (Emphasis added).

48 No. 45/ 1968.

49 Constitution Amendment Act No. 7/ 1982.

50 Presidential Circular No. 1/ 1987, Republic of Kenya, Office of the President, Nairobi.

51 Wade, E.C.S. \& Phillips, G. Constitutional and Administrative Law, 9th ed. - see generally 98-103.

52 This position may change after the 1988 general elections in view of the increase of electoral constituencies by thirty - see The Parliamentary Constituencies Review Order L.N. No. 370/ 1986. 
say, "Oh yes, Mr. President, all right." They will do that, because there are those who fear to speak their minds. They say "yes " here, and they will go on saying "yes", because there are very few people who dare to speak their minds. Some of us feel, if you dare say this you will be considered a bad boy . . « ${ }^{52 a}$

Thus, Parliament's power to "revoke these powers at any time « cannot be assumed. And if that is so, then the constitutional validity of these special powers is in doubt.

It may be concluded that the constitutional validity of the laws that currently enable the detention of persons without trial in Kenya is doubtful. This is because derogations from the right to personal liberty have constitutional validity only in times of emergency, and even then, if the powers subsist only for the duration of the emergency. There was no emergency situation in Kenya at. the time the powers were invoked. Also, as they stand at present, these powers bear a most permanent countenance, one that denies them constitutional validity.

But, since the powers are in force it is necessary to analyse their operation with view to determining whether the safeguards provided against their arbitrary exercise have been effective.

\section{The Safeguards}

Three saf eguards have been pinpointed:

1. The writ of habeas corpus ad subjiciendum

2. The Detainees Review Tribunal

3. The High Court/ Judicial Review

\section{The Writ of Habeas Corpus ad Subjiciendum ${ }^{53}$}

The phrase habeas corpus ad subjiciendum means, "that you have the body to answer. ${ }^{54}$ This writ is a prerogative process for securing the liberty of the subject by affording an immediate means of effective release from unlawful detention, whether in prison or in private custody. ${ }^{55}$ It is addressed to the official who detaines another person, "commanding him to produce the body with the day and cause of his caption and detention, and to do, submit to and receive whatever the judge shall consider in that behalf. $~^{56}$ Modern practice, however, does not require production of the prisoner unless there are special circumstances. ${ }^{57}$

Dicey underscored the importance of this writ to the law of detention when he said:

52a House of Representatives Debates supra at n. 19 at 303.

53 In s. 389 of the Criminal Procedure Code Cap. 75 of the Laws of Kenya - which applies Habeas Corpus to Kenya - the word "order" is used instead of the word "writ". The quotations used in the paper refer to "writ" but the meaning is the same.

54 Oppe, A.S. Wharton's Law Lexicon, London, 1938 14th ed. at 462.

55 Sanders, J.B. Words and Phrases Legally Defined, vol. 2, London, 1969, at 341.

56 Oppe, supra. at No. 54.

57 Criminal Procedure (Directions in the Nature of Habeas Corpus) Rules, L.N. 474/ 1963, rule 12. 
"Liberty is not secure unless the law (...) provides adequate security that every one who, without legal justification, is placed in confinement shall be able to get free. This security is provided by the celebrated writ of habeas corpus. ${ }^{58}$

In R. v. Commissioner of Prisons ex parte Kamoji wa Wachira et al. ${ }^{59}$ Simpson C.J. held that one's detention begins on the date of service of the detention orders upon the detainee and not on the date of one's arrest. Therefore, even where a person is held for over fourteen days ${ }^{60}$ the holding does not by virtue of that fact alone become illegal as long as one has not been served with detention orders. In the view of Simpson, C.J., one's detention has not yet begun. In this situation, the writ of habeas corpus is the only safeguard the individual has got against being held indefinitely.

The writ is a common law writ which exists independently of statute, though it has been confirmed and regulated by statute ${ }^{61}$ Its application is based on the illegal detention of a subject. ${ }^{62}$ Also, it is a writ of right and is granted "ex debito justitie", that is, it is a writ which the court has no jurisdiction to refuse. ${ }^{63}$

It is not necessary that the application for the writ proceed directly from the person illegally detained. ${ }^{64}$ The application may be made by any person on an affidavit setting forth the reasons for it being made. ${ }^{65}$

If circumstances were to require it, an application for the writ may be made to a judge at any time of day or night or on Sunday. And in court, habeas courpus matters enjoy precedence over all other matters. ${ }^{66}$ The applicant has the right to apply successively to every competent court and each tribunal must determine such an application upon its merits, unfettered by the decision of any other tribunal of co-ordinate jurisdiction, even though the grounds urged are exactly the same. ${ }^{67}$

The writ is applied for ex parte and the court will then adjourn the case for argument between the parties, ${ }^{68}$ during which it concerns itself with the question whether the order of detention is made within jurisdiction or ought to be quashed, but not with the question of whether it is correct on its merits. ${ }^{69}$

A prisoner who has been discharged from illegal custody on habeas corpus cannot again be imprisoned for, or in respect of, the same offence. The writ is enforced by attachment for contempt.

Dicey, A.V., Introduction to the Study of the Law of the Constitution, 19th ed. London 1948 at 213. [Emphasis added].

59 H.C.C.C. No. 60/ 1984 (unreported).

60 Fourteen days is the maximum number of days for which one can be held before one's detention is gazetted under s. 83 (2) (b) of the Constitution.

61 Criminal Procedure Code supra at n. 53.

62 Halsbury's Laws of England, 3rded.v. 11, London 1955, at 25.

63 Ibid.

64 Ibid. at 37.

65 Ibid.

66 Sharpe supra at n. 6 at 221.

67 Halsbury's supra at $\mathrm{n} .62$ at 221.

68 Wade, H.W.R., Administrative Law, Oxford, 1977, at 519.

69 Ibid. 
The writ of habeas corpus has not been much used in Kenya. The reasons for this are not clear, but two factors can be adduced which have aggrevated this demonstrated apathy.

First, the court has not been demonstrably sympathetic to applications for the writ. For instance, George Anyona was arrested on Sunday, 30th May, 1982. On 31 st May, his wife instructed an advocate to prepare to file an application for habeas corpus should Anyona not be released or brought to court within twenty four hours. On the hearing of the application on the 2nd of June, 1982 the Deputy Public Prosecutor presented a detention order served on Anyona on 31 st May. I. Sachdeva thought that, as the 1 st of June had been a public holiday, there had been no unreasonable delay. In dismissing the application he said:

"Whilst no doubt rights of subjects are entitled to protection, I deprecate the practice of rushing to court without first ascertaining all the facts. ${ }^{70}$

This remark assumes added significance in light of the fact that Mrs. Anyona had, in October 1981, filed a similar application with the effect that her husband was brought to court. $^{71}$

If the learned judge was attempting to discourage habeas corpus applications, it does not augur well for the effectiveness of so important a safeguard.

Secondly, the executive's action in detaining one counsel, Mr. John Khaminwa literally days after he represented two persons - Mrs. Anyona and Mrs. Muriithi - in habeas corpus applications, must be contributive to the apathy towards the writ. Intended or not, this action could not fail to intimidate the legal profession and make it avoid the writ. The gravity of this effect increases due to the position that habeas corpus applications must be made by counsel, as the court will not, as a rule, allow an applicant to move in person. ${ }^{72}$

\section{The Detainees Review Tribunal}

The word "tribunal " does not have any ascertainable meaning in English law. ${ }^{73}$

But, the expression "statutory tribunal« means:

"(...) any government department, authority or person entrusted with the judicial determination as arbitrator or otherwise of questions arising under an Act of Parliament $(\ldots)^{74}$

Excepted from this definition are ordinary courts of law and arbitrators.

S.83(2)(c) of the Constitution requires that a detainee's case be reviewed not more than one month after the commencement of his detention, and thereafter, at intervals of not more than six months by an independent and impartial tribunal presided over by a Presidential

70 Weekly Review 4th June 1982 Weekly Review Ltd., Nairobi Under reg. 6 (2) of the Public Security (Detained and Restricted Persons) Regulations, a detention order is a satisfactory and complete answer to an application for habeas corpus.

71 Ibid.

72 Halsbury's supra at n' 62 at 37.

73 Sanders supra at N. 55.

74 Ibid. 
appointee. To this end, regulation $8(1)^{75}$ establishes a standing statutory tribunal, the Detainees Review Tribunal.

The jurisdiction of the Tribunal is to "review» the cases of the detainees. However, the final decision shall be that of the Minister, who shall not condiser the recommendations of the Tribunal binding. ${ }^{76}$ This, no doubt, considerably limits the effectives of the Tribunal as a safeguard in the proper exercise of the power to detain.

An essential feature of tribunals is that they make their own decisions independently and free from political influence. ${ }^{77}$ To facilitate this, every member of the Detainees Review Tribunal has privileges, protections and immunities similar to those conferred upon a judge. $^{78}$

But in Ooko v. $\mathrm{R}^{79}$ evidence showed that a senior police officer and a state counsel from the Attorney General's chambers, both non-members of the Tribunal, attended its proceedings. J. Rudd saw no reason why such people should not be present. In fact, he said, their presence is desirable and necessary. Moreover, there was no evidence that they took part in the recommendations of the Tribunal. This reasoning appears not to give sufficient weight to the provision that the proceedings of the Tribunal shall not be public. ${ }^{80}$ Due to this provision, only persons appearing in an official capacity may be present at the proceedings. Therefore, the presence of senior police officers and state counsels lacks legal justification. And, given their status, their presence might have an inhibiting effect on the proceedings.

Secondly, both Ooko v. $\mathbf{R}^{81}$ and $\mathrm{R} v$. Commissioner of Prisons ex parte Kamoji wa Wachira ${ }^{82}$ held that it is to the Tribunal that the detainee should apply for grounds of his detention. Despite these holdings, the Tribunal never supplies such grounds. ${ }^{83}$

In the face of the lack of grounds of detention, the question arises regarding the nature of representations a detainee appearing before the Tribunal makes. It appears that representations are made on personal matters such as, the health of the detainee and the duration of detention. ${ }^{84}$

Apparently, the Tribunal perceives its reviewing jurisdiction in particularly restrictive terms. If that is so, it is not likely to effectively safeguard the proper exercise of the power to detain.

75 Public Security (Detained and Restricted Persons) Regulations which are made under the Preservation of Public Security Act.

76 S. 83 (3) of the Constitution.

77 Wade supra at n. 68 at 746.

78 Reg. 11 of the Public Security (Detained and Restricted Persons) Regulations at $n$. 75 supra.

79 H.C.C.C. No. 159/ 1966 (unreported). The account relied on here is from Ghai Y \& McAuslan, Public Law and Political Change in Kenya, Oxford 1970, at 438.

80 Reg. 10 of the Public Security (Detained and Restricted Persons) Regulations supra at n. 75.

81 Supra at n. 79.

82 Supra at $n .59$.

83 Ngugi wa Thiong'o, Detained, A Writer's Prison Diary, Nairobi 1981, at 149. See also Weekly Review, 5th January, 1979 at 30 .

84 This information was gathered from Mr. Kamau Kuria who has represented detained persons before the Tribunal. See also Ngugi ibid at 148. 
In fact, far from serving a safeguarding function, the tribunal seems to serve the purpose of a screening team and a body to allay international fears regarding detention.

As regards the first, President $M o i$ said:

"It has always been my wish and intention to lift the detention measure on the individuals involved as soon as it was established that they have reformed, and each detainee's case is reviewed from time to time. With this objective in mind, I have today decided to release those detainees who have shown signs of reform $(..){ }^{85}$

It appears that the purpose for the review of the cases of detained persons is to determine whether or not they have reformed and not at all to determine the propriety of the detention measure against them.

Regarding the second, Article 40 of the International Covenant on Civil and Political Rights $^{86}$ requires that State parties ${ }^{87}$ submit reports to the Human Rights Commission "on measures they have adopted which give effect to the rights . . . and the progress made in the enjoyment of the rights. "Arguably, reports sent regarding the detention measure might refer to the Tribunal as a "measure adopted which gives effect to the rights ..."

\section{Judicial Review}

The jurisdiction of the High Court to review acts of detention is based on s.84 of the Constitution. In addition to this statutory jurisdiction, the High Court has inherent jurisdiction to determine, whether an administrative act is lawful or not, and to grant relief. ${ }^{88}$ For this, no statutory authority is necessary as the High Court is simply performing its ordinary function in order to uphold the rule of law. ${ }^{89}$ The basis of judicial review in this latter sense is the common law which applies to Kenya by virtue of s.3(1) of the Judicature Act. $^{90}$

The High Court has to date pronounced on four issues:

1. The lack of detail in the statement of reasons for detention;

2. The date on which detention starts;

3. The effect of a defective detention order;

4. The request to constitute a constitutional court.

These issues will be analysed in turn.

1. The Lack of Detail in the Statement of Grounds:

S.83(2)(a) of the Constitution requires that a detained person be furnished with a statement in writing specifying "in detail« the grounds upon which he is detained.

85 Daily Nation, 13 December 1984. Emphasis added.

86 International Legal Materials, vol. VI No. 2, at 368.

87 International Legal Materials, vol. XV No. 1 at 217 Kenya ratified the convention on 1st May, 1972.

88 Wade supra at n. 68 at $36-37$.

89 Ibid.

90 Chapter 8, Laws of Kenya, Government Printer, Nairobi 1983. 
Detailed grounds act as a safeguard in two material respects. First, in ensuring that the detaining authority has reason to detain the individual. Second, in giving the detained person a chance, should the detaining authority be mistaken, to convince the detaining authority of his innocence when he appears before the Detainees Review Tribunal for, without these grounds, "an innocent person would not know where to start. «"1

The problem concerns the degree of detail required to satisfy the constitutional requirement. Doyle, C.J. of the High Court of Zambia opines that, it is not possible to determine the meaning of the words "in detail « in vacuo, by a simple reference to the dictionary definition or, by any rigid yardstick. In his words, wit is a matter of fact in the particular circumstances of each case what and how much detail must be given. ${ }^{92}$

But, the matter must be looked at from the point of the detainee himself. Therefore:

"Such grounds must enable the detainee to make representations not only on the basis of mistaken idenity, alibi and the like, but also on the merits (. . .) the detainee must be put in a position where he can dispute the truth of the allegations against him. $"{ }^{92}$

For this purpose, "a ground which is vague, roving and exploratory is insufficient. ${ }^{94}$ One statement served on a Kenyan detainee in the 1960s stated that:

"As a leading member of the trade union movement you have consistently pursued the role of an agitator and have sabotaged not only the good relations in the labour field but also the labour policy of the government by threatening illegal strikes in essential services thus adversely affecting the economy of the country and thereby the security of the republic. . $^{95}$

Rudd, J. found this statement insufficiently detailed.

Surprisingly, the statements served on detained persons since this holding have consisted of two standardised lines, stating that:

"You have consistently engaged yourself in activities and utterances which are dangerous to the good government of Kenya and its institutions.

In order to thwart your intentions and in the interest of the preservation of public security your detention has become necessary. ${ }^{96}$

Simpson, C.J. appropriately described this statement as a "stereotype ${ }^{97}$

But Mandan, C.J. thought that even this statement can be sufficiently detailed, depending on the circumstances of the case. In his words:

"In both cases it is a relative term. What appears insufficient or sufficient on the face of it may indeed be sufficient when combined with other knowledge of the person concerned. $\ll^{98}$

91 In the Matter of Kapwepwe and In the Matter of Kenya Z.L.R. 248 (1972) at 254.

92 Ibid.

93 Ibid at 260 - quoting Baron, J.P.

94 Ibidat 253.

95 P.P. Ooko supra at n. 79.

96 Ngugi supra at n. 83 - see Appendix. See also R.v. Commissioner of Prisons supra at n. 59 and also Raila Odinga v. The Attorney General at al H.C.C.C. No. 104/ 1986 (unreported) at 3.

97 R. v. Commissioner of Prisons - ibid.

98 Raila Odinga supra at n. 96 at 8. 
He saw two circumstances in the case before him which made the statement sufficiently detailed.

First, the detained person "had been the actor who put in motion events and stirred up circumstances known to him which admittedly necessitated his detention." Secondly, the detained person shad solemnly declared that upon re-examination of the detention order ... he was satisfied that the grounds therein contained were indeed sufficient to warrant his detention and he did not require any further elaboration. $"{ }^{99}$ Under these circumstances, his Lordship thought that for the detained person to seek the court's assistance was "a limping and pedantic peroration. " $" 100$

Taking the second set of circumstances first, although one has to take the detained person's declarations in good faith, contrary evidence being absent, it is significant that the detained person made the declaration "upon re-examination of the detention order." And this, after over one year in detention. Why, one might validly ask, did he not find the statement sufficiently detailed upon his first examination of it at the commencement of his detention?

Regarding the first set of circumstances, it is surprising for a court to assume that the detained person was "the actor who put in motion events and stirred up circumstances which necessitated his detention." This, because unless the court has pre-judged the issue, it cannot know whether indeed it is the detained person who put in motion events and stirred up circumstances. All it has to go on are the detaining authority's allegations to that effect. In fact, were the guilt of every detained person to be presumed, any sort of statement (or even, none at all) would suffice, because all detained persons would then know the grounds warranting their detention.

Then, there is the effect of lack of detail in the statement. In R v. Commissioner of Prisons ${ }^{101}$ it was contended on behalf of the four detained persons that: (1) the statements were not sufficient to comply with the provisions of S.83(2)(a), and (2) compliance is mandatory and insufficiency of details invalidates the detention orders.

But Simpson, C.J. thought, as did Sir Udo Udoma in Uganda v. Commissioner of Prisons ex parte Matovu, that minsufficiency (. . .) is a mere matter of procedure. It is not a condition precedent but a condition subsequent (. . ) it is not fatal to the order of detention ${ }^{102}$ And that

"Insufficiency is a relative term and whereas in some cases insufficiency is obvious on the face of the statement, in others a stereotype statement which to one detainee might contain information sufficient to enable him to know what is being alleged against him might convey nothing to another. In such a case the court has to base its decision on the evidence of the detainee, assessing his credibility, knowledge and intelligence, a far from sound basis on which to make a finding of invalidity. ${ }^{103}$

99 Ibid at 9 - Emphasis added.

100 Ibid.

101 Supra at n. 59.

102 E.A. (1966) 514 at 546.

103 Supra at n. 59. 
His Lordship confused two distinct and separate issues. A court faced with two contentions, as this one was, has to adopt a two-step procedure. First, determine whether or not in the case before it, the statement is sufficiently detailed. Should it decide that the statement is sufficient, having taken into account the relativity of the term sinsufficiency", it does not proceed to pronounce on the effect of an insufficient statement, for that issue is then moot. But should the court - as did this one - determine that the statement is insufficient, it then proceeds to consider the effect of that insufficiency. At this second stage the Court cannot again revive the issue of the relativity of the term "sufficient « for, in the case before it, that term is no longer relative. An absolute meaning - one of insufficiency - has been given it.

Then, the argument that insufficiency is a condition subsequent and not a condition precedent, even if correct, need not prevent the court from making a finding of invalidity. In Attorney General v. Chipango ${ }^{104}$ the Court of Appeal of Zambia held that, although failure to give reasons was not a condition precedent, invalidating the detention, it made further detention unlawful. In the Court's view, the provision of detailed reasons was an essential prerequisite to valid imprisonment beyond a certain point. Further, that "these conditions are mandatory (. . .) and if they are contravened they render the continued detention of the applicant unconstitutional ans unlawful «. ${ }^{105}$

\section{The date on Which Detention Begins:}

S. 83(2)(b) requires that not more than fourteen days after the commencement of a detention, a notification must be published in the Kenya Gazette to this effect. Such publicity is, no doubt, a singularly potent saf eguard against arbitrariness.

In R. v. Commissioner of Prisons ${ }^{106}$ it was argued on behalf of two of the detained persons not only that grounds of their detention were not served on them within five days as is required by S.83(2)(a) of the Constitution, but also that notifications of their detentions were not published in the Gazette within fourteen days of the commencement of their detention. Kamoji wa Wachira was arrested on 29th June 1982 and served with a detention order dated 13th July 1982 and a statement of grounds on 15th July 1982. His detention was gazetted on 15 th July 1982 . Thus, he had been in custody for seventeen days before he was served with a statement of reasons and, for fifteen days before his detention was gazetted. Dr. Oyugi was arrested on 15 th June, 1982, served with a detention order dated 13 th July 1982 and a statement of reasons on 15 th July, 1982. His detention was gazetted on 13th July, 1982. Thus he had been in custody fot thirty days before he was served with a statement of grounds and, for twenty eight days before his detention was gazetted.

Counsel for the detained persons contended that the date of arrest was also the date of the commencement of detention. The Attorney General argued that, on the contrary, detention commenced with the service on the detained person, of a detention order. 
Simpson, C.J. agreed with the Attorney General because:

sA person may be arrested in the course of police inquiries on a suspicion of commission of criminal offence or of activities which might justify a report to the Minister responsible for making detention orders. Subsequently such a person while still in custody might be served with a detention order (. . .) Detention (. . .) commences (. . .) on the date of the detention order where a person is already in police custody and in other cases, with the service of the detention order. «107

S. 72 (3) of the Constitution requires that any person arrested or detained upon reasonable suspicion of having committed, or being about to commit, a criminal offence shall be brought to court within twenty four hours.

Logically, if not brought to court or released within that period and also not served with a detention order, one is held without any legal authorisation. An interpretation such as the one in this case creates a lacuna in the law, enabling a person to be held indefinitely.

\section{The Effect of A Defective Detention Order:}

Ooko ${ }^{108}$ contended that his detention was not valid since he was detained under a wrong name. The court accepted that a warrant of arrest applied for in a name which was not that of the person arrested and intended to be arrested does not justify the arrest of that person. But in Rudd, J. view, the same principle does not apply to detention orders because:

"(...) in view of the seriousness of the conditions precedent to the issue of a detention order in as much as the Minister must be satisfied that the detention is necessary for the preservation of public security, a partial mistake in naming the person to be detained should not necessarily have the effect that the person should be released from detention when he is the person intended to be detained and there is in fact no confusion as to the real identity of that person. «109

One would have thought that the very seriousness of the conditions precedent to the issue of a detention order should raise the presumption of arbitrariness in the case of a defective detention order. As Doyle, C.J. said:

"The very fact that a defective order has been passed (...) bespeaks negligence on the part of the detaining authority and the principle underlying s. 13 (2) [protective provisions ] is (...) the outcome of insistence by Parliament that the detaining authority shall fully apply its mind to and comply with the requirements of statute and of insistence upon refusal to countenance slipshod exercise of power. ${ }^{110}$

107 Ibid.

108 Supra at n. 79.

109 Ibid.

110 Supra at n. 104 quoting Hadhibadhu Das v. District Magistrate of Cuttack and Another A.1.R. (S.C.) 43 (1969) at 44. 


\section{The request for a Constitutional Court:}

In the Matter of Gibson Kamau Kuria ${ }^{111}$ counsel for the applicant requested that a constitutional court ${ }^{112}$ be set up for two reasons.

First, that the Minister does not have absolute and unfettered powers in respect of making detention orders. That the Court had jurisdiction, right and duty to judicially examine and evaluate, on behalf of a citizen, the validity of a detention order and satisfy itself that the grounds put forward by the Minister as basis for an issue of the detention order, were themselves valid. And that the court's role was fundamental in holding the scales even between the executive and the citizen.

Second, that S. 84 (1) of the Constitution states that a citizen who alleges that his fundamental rights have been contravened may apply to the High Court for redress. That the applicant's fundamental rights had been contravened and that he would like to urge for redress before such constitutional court.

Tanui, J. declined to adjudicate on these submissions since there was no proper application before him to ref er the matter to the Chief Justice for purposes of setting up a constitutional Court. In his view, "a court of law can and must adjudicate only upon a matter before it and no more no less." Therefore "there is nothing this court can do."

But, his Lordship interpreted the scope of his jurisdiction unduly restrictively. S. 67 (1) requires that a subordinate court refer a question regarding the interpretation of the constitution to the High Court whenever such "arises in the course of proceedings." There is no necessity for a party to make a formal application to this effect. Arguably if a subordinate court does not need a formal application, neither should the High Court which in fact has unlimited jurisdict. To insist otherwise is unduly legalistic, and so to the detriment of the individual detained.

In conclusion, it appears that the High Court has adopted a policy of invariably resolving any doubt in the law agains the liberty of the individual. This contrasts sharply with that of the High Court of Zambia that:

"S. 264 [read s.83 in Kenya - M] appears in a part of the Constitution which has deliberately and formally set out to enshrine the rights and freedoms of the people of Zambia. It is a section introduced to provide for the protection of those rights and freedoms and where possible it should be interpreted effectively to protect those rights and freedoms. That the protection given is limited protection is no reason for cutting down what is given. ${ }^{113}$

111 H.C.C.C. No. 53/ 1987 (unreported).

112 S. 67 (2) of the Constitution provides for the setting up of a court of not less than three judges to determine a constitutional question which arises in the course of proceedings in a subordinate court. There is no comparable provision regarding proceedings in the High Court since under S. 60 (1) the High Court has unlimited original jurisdiction. The request here was therefore unnecessary as the Court being a High Court, had jurisdiction to determine the matter.

113 Supra at n. 104 at 7. (Emphasis added). 


\section{Concluding Remarks}

The preservation of public security through executive restraint of personal liberty as currently obtaining in Kenya runs counter to the theory of constitutionalism, a theory at the base of Kenya's political system. But, and this is even more significant, the actual operation of the laws in place also with impunity runs counter to the letter and spirit of Kenya's own constitution. And this may pose a serious threat to the rule of law in the country. 
to be owned publicly, either by the state (the "whole people«) or by collective organizations. Both the Constitution and the Civil Law, however, specifically permit ownership of certain property by individual citizens. The purpose of this paper is to explore the scope of a citizen's individual ownership, as provided in the Civil Law and other recent legislation enacted as part of the PRC's economic reforms.

Two main questions are considered: (1) what types of property may an individual own and (2) what other property rights related to ownership may an individual have. The conclusion is that in the PRC an individual may have ownership rights in a wide range of property, including those classified as means of livelihood and means of production; and he may obtain extensive rights related to property in other means of production, land and natural resources. The current position represents a marked change from past views in the PRC and also from the law of some other socialist countries.

\section{Preservation of Public Security Through Executive Restraint of Personal Liberty: A Case Study of the Kenyan Position}

\section{By Albert O. Mumma}

The paper argues two points. One that the provisions that empower the executive to administratively detain persons without trial in Kenya lack constitutional validity. Two that whatever safeguards are in place for the supervision of the exercise of these powers with a view to the protection of the rights of the detained person have proved ineffective.

The view is advanced that the validity of constitutional powers is a matter to be determined objectively rather than subjectively. This requires that their exercise conform to objectively determinable criteria. In the area of individual rights and freedoms these criteria are to be found in the state's obligations under the relevant international conventions and also in the objective circumstances obtaining in the country in question at the time of the exercise of these powers. Therefore, the bare assertion by the executive that an emergency situation exists severe enough to necessitate its resort to detention powers will not suffice. Under these criteria the situation in Kenya does not warrant resort to detention powers.

It is normal to enshrine saf eguards against the arbitrary exercise of detention powers. In Kenya these saf eguards have not worked to protect the detained person. In fact the ultimate safeguard, the courts, have themselves contributed to this failure by invariably interpreting any doubt in the law against the liberty of the subject. The paper concludes by pointing out that the combination of invalid emergency powers and ineffective safeguards against their arbitrary exercise poses a threat to the rule of law in the country. 